\title{
The Development of Young Learner Material for Teaching English
}

\author{
Ulhaq Zuhdi \\ Department of Primary Teacher Education \\ Universitas Negeri Surabaya \\ Surabaya, Indonesia \\ ulhaqzuhdi@unesa.ac.id
}

\begin{abstract}
This study aims to know the Effectiveness of Student Textbooks for TEYL Teaching English for Young Learner or Primary School. Primary Teacher Education Students as agents of change will carry out the mandate of the law, that will educate the nation. Based on the theory in the background that the earlier the children are taught a foreign language, the better the abilities they will receive. Through the Teaching English for Young Learner (TEYL) they sharpen their teaching skills. The results showed that calculating the test scores on product trials after using the TEYL Student Textbook showed a significant value because the calculated $t$ value was greater than t table.
\end{abstract}

\section{Keywords-textbook; TEYL; primary teacher education}

\section{INTRODUCTION}

English subjects can be officially taught in elementary school since the 1994 school year as learning local content. But in practice in elementary schools have implemented English language learning before that year [1]. The Indonesian government, in this case the Ministry of National Education, has made learning English as a foreign language at the elementary school level from urban to villages throughout Indonesia. Learning English at the elementary level is of concern to experts in the field of language learning especially English in Indonesia.

One reason for the Indonesian government to introduce English to elementary school children is based on the fact that English is used in every aspect of people's lives in the world, especially in ASEAN communities such as Indonesia in facing ASEAN Economic Community (AEC) [2]. ASEAN Economic Community).

Learning English in Integrated Islamic Primary School or private elementary schools is increasing. The stakeholders or users prefer Primary School plus which has ability teaches English as a foreign language. Stakeholders prefer schools that teach English as a foreign language due to several reasons [3]. English is the language most widely used throughout the world. It can be seen if there is an international conference or meeting in the world, they use English. It is needed by the state or international companies. Without mastering English as a foreign language, it is impossible to establish good communication and cooperation with the international community. Furthermore, English is important because almost all knowledge in accredited international journals which is written in English as a scientific language.

Approach to learn play and song children will be easier to remember the lessons delivered. In both activities, children will be directly involved in the learning process so that they will be more active in the learning process [4]. In game, it can be inserted very simple sentences related to the theme that is being studied, as well as the song to be sung. In the learning process, the teacher must be able to connect the learning process that relates to the knowledge that the child already has to be associated with the material to be learned. This is so that the learning process will take place effectively and the learning objectives will be achieved, because if students cannot connect the knowledge, they have with the lessons being studied it means there is no learning process.

Based on the theory of acceptance of children's language which is viewed from the point of view of psycholinguistics, children's learning at the elementary school level can be implemented but must be in accordance with the characteristics of elementary students [5]. For this reason, a study is needed: The Development of Student Teaching Materials for Teaching English for Children (TEYL / as a material book for Students of Primary Teacher Education (PGSD) FIP (Education Faculty) UNESA [6].

PGSD students or candidate of teacher who is going to teach Primary School as agents of change will carry out the mandate of the law [7]. Based on the theory in the background that the earlier children are taught a foreign language, the better the abilities they will receive. Through the Teaching English for Young Learner (TEYL) material they sharpen their teaching skills [8]. Like an old time learning proverb like carving on a rock and learning in childhood as carving on a rock. Interpretations of proverbs that say that science has been learned since childhood will be well embedded than learning in old age [9].

From the description, the problems that will be solved is can be formulated as follows: How is the effectiveness of the Development of Student Materials for Teaching English for Young Learner (TEYL) for PGSD FIP UNESA Students?

The results of the composing of the material are expected to provide the following benefits: To describe the effectiveness of the Development of Student Teaching Materials for Teaching 
English for Young Learners (TEYL) for PGSD FIP UNESA Students.

\section{METHOD}

This research is a development research model. Borg and Gall simplified 10 steps in developing mini learning into 5 main steps, namely (1) analyzing the products to be developed, (2) developing initial products, (3) expert validation and revision, (4) small-scale field trials and product revisions and (5) large-scale field trials and final products [10]

Referring to Borg and Gall, with a modification for a span of 8 months, then develop a product namely Student Textbook - Teaching English for Young Learners which includes:

\section{1) Collecting Data}

\section{Week Learning Outcome}

1-2 Understand the nature of teaching English in elementary schools

3-4 Understand the characteristics of learners of English in Primary School and the characteristics of EYL teachers (English for Young Learner)

5-6 Understanding Practicing Teaching Technique in EYL

6 Understand Fun activities (Games) for Teaching English for elementary school children

7 Understand Fun activities (Songs) for Teaching English for elementary school

8 Mid Exam

9 Designing Productive Language Skills (Listening and Speaking) on Primary Students English Learning

10-11Understanding Language Component Learning in Primary Students English Teaching classes

12 Designing Media and Its Use in Primary English Learning

13-14 Collecting TEYL Learning Videos and Making into TEYL Learning Media

15 Formulate authentic assessment and its application in Primary school English learning

16 Final Examination

2) the implementation stage, namely compiling BAM Teaching English for TEYL children to complete, setting towards multiplication in the form of book printing, 3) feasibility testing phase, which is limited to the results evaluated by 2 experts from academia by English and media experts, 4 ) limited test for Education Faculty UNESA Academic Community, 5) revision of English Language BAM (Teaching Material) for TEYL students from several aspects of the field of study such as (content rules, consistency of captions in each competency and practitioner side related to material, and material weights ) After going through these stages, Teaching English for Young Learners - TEYL is recommended as one of the Student Textbooks that is useful in the Academic Community of UNESA.

\section{Research Design}

The design of the research implementation has been designed as in the chart below;
This research is a type of research and development which uses the research model modified Borg and Gall with 10 stages of research. Next the researcher modifies these stages into 9 research stages, among others; (1) potential and problems; (2) Data collection; (3) product design; (4) design validation; (5) design revisions; (6) product testing; (7) product revisions; (8) experiment; and (9) product revisions. From the above stages, it is further classified into 3 research stages, namely; (1) preliminary study phase; (2) development stage; and (3) experiment phase [11].

\section{RESULTS AND DISCUSSION}

This research is a development research model. Borg and Gall (2003) simplified 10 steps in developing mini learning into 3 main steps i.e.: (1) analyzing the products to be developed, (2) developing initial products, (3) expert validation and revisions.

The purpose of the activity in $1^{\text {st }}$ stage is the assessment and identification of problems and the realities that occur about development. Activities carried out include (1) Survey and observation of needs analysis, analysis of constraints on classroom observations related to teaching materials. Student interviews related to the activities they do in lectures, and the efforts of the Primary School to optimize student competence through the TEYL Teaching English for Young Learners book. Obstacle analysis is illustrated by the problems faced by students in improving the ability to teach elementary English, through TEYL book users can improve their ability to teach English for Primary School.

After testing the product in small groups, there are inputs, in BAM Teaching English media for children - TEYL must be equipped with a complete reference to the standards that must be met by candidate elementary English teachers. The results of the experiments is used to improve the final product before the Product Development Research ends.

Product revision along with progress and improvements that have been achieved to become the final report of research activities from the third month to the last is

There has been media development from media experts and material experts related to the development of Teaching English for Young Learner - TEYL from the concept stage to the design stage. After that through the stages of collecting material that includes material that is in accordance with the development of English language skills of Primary School students.

Design (prototype) of designing BAM Teaching English for Young Learner - TEYL has produced media to produce a flow of foreign language learning that is in accordance with the characteristics of elementary school children.

From the design (prototype) is to make specifications that are more detailed about the program architecture, style, appearance and material and program requirements. The specifications are made quite detailed so that in the next stage Material Collecting more developed and directed and uses what is appropriate at the design stage. However, frequent additions 
or changes in the display section or application parts are omitted or added to this design.

Using Indonesian language as in the Teaching Textbook for Teaching English for children - TEYL, which make easier for users.

English Teaching Book for children or BAM - TEYL which has been compiled based on the material to be presented has been reviewed by experts, The material presented reflects the description that supports each discussion, The material presented starts from the introduction of concepts, definitions, procedures, output displays and examples, concepts and the definition presented does not cause many interpretations and is in accordance with the concepts and definitions that apply in the field of science, facts and data presented in accordance with reality and efficiency to improve understanding, drawing diagrams and illustrations that are presented in accordance with reality and are efficient to improve understanding, diagrams and illustrations that are presented in accordance with reality and efficient.

The results of the t-test calculation are t count values or also called $t$ empiric (t_e). To determine the significance level can use $t$ table in the value table $t$. To see the $t$ value of the table then first determine the degree of freedom $(\mathrm{db})$ using the formula $d b=N-1$. The results of $d b$ are then seen in table $t$ with a significant level of $5 \%$ to determine the level of error when tested at $5 \%$.

The data shows the acquisition of a value of 4.372 which is called $\mathrm{t}$ count or empirical ( $\mathrm{t}$ e e). At $\mathrm{db}=\mathrm{n}-1=10-1=9$, a significant level of $5 \%$ is obtained t table of 2,262. From these results, it can be seen that the value of $t$ count is greater than $t$ table $(4,372>2,262)$. Thus, $t$ _e or $t$ calculate the value of the test on the product trial after using the TEYL Student Textbook Give My Answer to the material on teaching English skills for elementary school children experiencing a significant increase compared to before using Teaching Material TEYL.

\section{CONCLUSION}

From the results of this study, it is expected that BAM TEYL Teaching English for Young Learners is useful for students of the PGSD FIP UNESA class.

The BAM TEYL Teaching English for Young Learners book was compiled and developed with the relationship of thematic learning with blended learning which made teacher candidate improve their abilities in teaching. This makes Teaching English for Young Learners book improve the ability to teach elementary English and improve their English skills for primary school children.

\section{REFERENCES}

[1] Chern, C. L. . English language teaching in Taiwan today. Asia Pacific Journal of Education, 22(2), 97-105. 2002.

[2] Zein, S. The pedagogy of teaching English to young learners: Implications for teacher education. Indonesian JELT, 12(1), 61-77. 2017

[3] Yulia, Y.. An evaluation of English language teaching programs in Indonesian junior high schools in the Yogyakarta province. 2014.

[4] Kırkgöz, Yasemin. "A case study of teachers' implementation of curriculum innovation in English language teaching in Turkish primary education." Teaching and Teacher Education 24.7: 1859-1875. 2008.

[5] BRISK, María Estela. Engaging students in academic literacies: Genrebased pedagogy for K-5 classrooms. Routledge, 2014.

[6] Lestiono, riski, et al. Designing reading strategy guideline "dialogic reading" for extra curricular activities in primary schools. 2017.

[7] Zein, Mochamad Subhan. "Language teacher education for primary school English teachers in Indonesia: Policy recommendations." 2013.

[8] GHOSN, IrmaKaarina. Storybridge to Second Language Literacy: The theory, research and practice of teaching English with children's literature. IAP, 2013.

[9] FOGARTY, Robin J.; STOEHR, Judy. Integrating curricula with multiple intelligences: Teams, themes, and threads. Corwin Press, 2008.

[10] Ain, Nurul. "Developing Prophetical Stories as a Character-Based English Learning Source." JEELS (Journal of English Education and Linguistics Studies) 1.12014.

[11] Garrison, D. Randy, Terry Anderson, and Walter Archer. "Critical thinking, cognitive presence, and computer conferencing in distance education." American Journal of distance education 15.1: 7-23. 2001. 